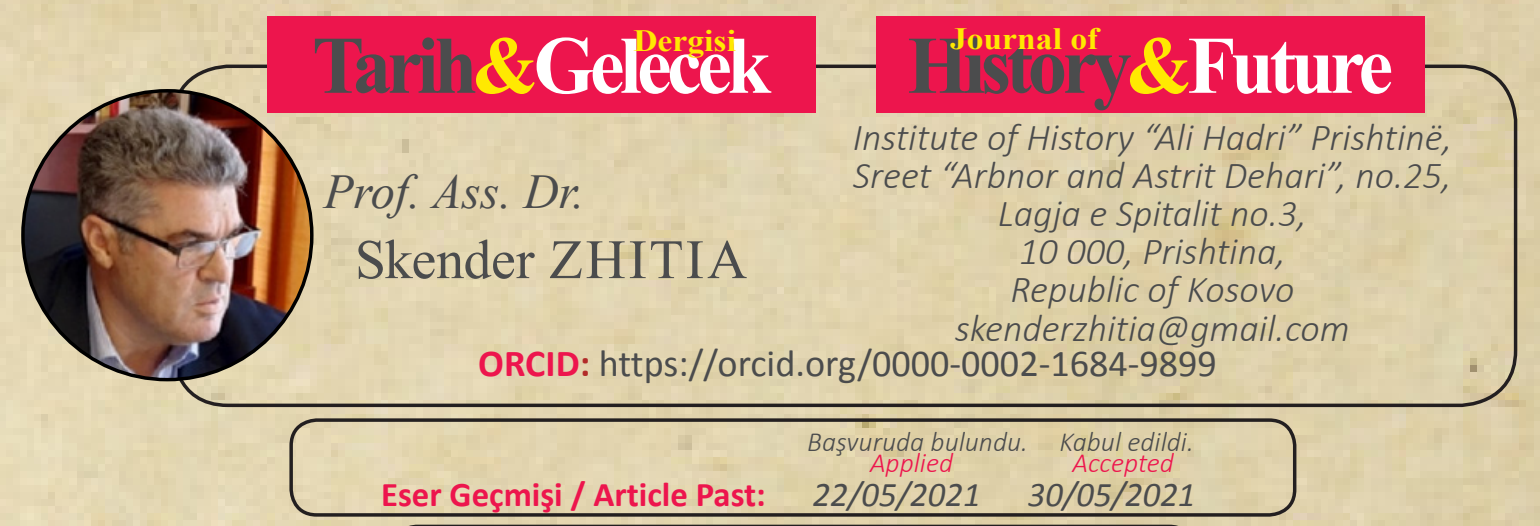

Araştırma Makalesi

DOI: http://dx.doi.org/10.21551/jhf.939845

Research Paper

Indexed by

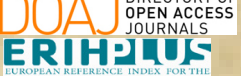

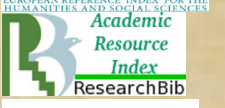

R]ISA $\mathbf{I}$

Orjinal Makale / Orginal Paper

\title{
The Anti-Albanian Policy of the Serbian State, Programs and Methods (XIX-XX)
}

\section{Sırp Devleti'nin Arnavut Karşıtı Politikaları, Programları ve Yöntemleri (XIX. ve XX. yüzysllarda)}

\begin{abstract}
From the beginnings of the independence of the Serbian state (at the beginning of the XIX century), its leaders showed expansionist interests in the (occupied) territories and people living within the Ottoman Empire. This case includes territories inhabited by Albanians (who, being the majority of the Islamic faith, were considered part of the Muslim population in the Balkan Peninsula). These anti-Albanian interests, initially through policies, programs and methods, prepared the national and the international opinion about the annihilation and colonization intentions on the territories inhabited by Albanians, especially in Kosovo. In addition to this, in the historical retrospect, Albanians during the XIX-XX centuries faced orthodox political calls for the creation of a state with Serbian orientation in the territories of the former Serbian king Car Dushani (1331-1355), with clear intentions for a Great Serbia to be formed (all Slavs in one state) for all South Slavs, where Serbia would have the leading role. Albanians were faced with the denial of everything non-Serb and with the call: "Wherever there is a single Serb, the Serbian state must also take its place there." Albanians were systematically confronted with new Serb programs, which went to extremes, aiming to destroy an entire nation. This anti-Albanian campaign, this state terror (also supported by the Serbian church) was executed with harsh measures, forms and methods that resulted in Albanians being killed, wounded, and imprisoned.
\end{abstract}

Keywords: Kosovo, Serbia, Anti-Albanian Policies, Plans, Programs.

Öz

Sırp Devleti’nin bağımsızlığının başlangıcından itibaren (XIX. yüzyılın başlarında) (Sırp) liderlerde Osmanlı İmparatoluğunda yaşayan diğer toplumlara ve topraklarına karşı yayılmacı çıkarlar görünmeye başladı. Bu durumda arnavutların yaşadığı topraklar söz konusudur (Arnavutlar çoğunluk olarak Müslüman olduklarından dolayı, Balkan Yarımadası'ndaki Müslüman nüfusun bir parçası

ATIF: ZHITIA Skender, "Sırp Devleti'nin Arnavut Karşıtı Politikalari, Programlari ve Yöntemleri (XIX. ve XX. yüzyıllarda)", Tarih ve Gelecek Dergisi, 7/2 (Haziran 2021), s. (691-710) 
olarak kabul edilmiştir). Bu arnavut karşıtı çıkarlar başta siyaset sayesinde, (Sırplar) programlarla ve yöntemlerle iç ve uluslararası görüşünü şekillendirip yök etme hedefinde arnavutların yaşadığı toprakları ve özellikle Kosovayı sömürgeleştirmek hedefliyorlardı. Üstelik, tarihsel retrospektif içinde, arnavutlar XIX-XX yüzyıllar boyunca Sırp Kralı Çar Duşan`ın (1331-1355) eski topraklarında Sırp merkezli bir devletin kurulması için ortodoks siyasi çağrılarla yüzleştiler, amaçları açık Büyük Sırbistan için (bütün sllavlar bir devlet içinde) bütün güney sllavlar için alarak bu devlet Sirbistan öncülüğünde olacaktı. Arnavutlar Sırp olmayan her şeyin reddedilmesi ve çağrılara "Nerde tek bir Sırpa bulunursa Sırp devleti de oradaki yerini almalıdır” karşı karşıya kaldılar. Arnavutlar sistematik olarak yeni büyük-Sırp programları ile karşılaşıp bu programlar aşırıya kaçıp bütün bir halkı yok etmeye hedefliyorlardı. Arnavut karşıtı kampanya, bu devlet terörü kitlelerle gerçekleştirilip sert metod ve yöntemlerle Arnavutların öldürülmesine, yaralanmasına ve aynı zamanda hapsedilmesine neden oldu.

\section{Anahtar Kelimeler: Kosova, Sıbistan, Arnavut Karşıtı politikları, Planlar, Programlar.}

\section{The beginnings of the anti-Albanian policies of the Serbian state}

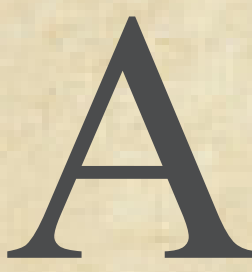

lbanians at the time of the national awakening in the Balkans (early nineteenth century) encountered many difficulties; above all, they faced the opposition of the neighboring countries and their conquest intentions. Evidence of this is not only the national chauvinist programs implemented on Albanians in a Serbia-Bulgaria-Greece triangle ("Nachertania," "Otoçenstvo" and "Megaliidea") but also their genocidal practice in the occupied territories, as was Sanjak of Niš (18771878).

Based on the studies so far, not only of Albanian historiography, Serbian nationalism has had its beginnings, extension and expansion based on the platform designed by the Orthodox Church for a pan-Slavic movement since $1814 .{ }^{1}$ The (Russian) Orthodox Church at that time expressed its eagerness for the creation and development of a Pan-Slavic empire, which would extend in latitude and longitude from the Pacific Ocean in the east to the shores of the Adriatic in the west and from the North Sea to the south, in the waters of the Indian Ocean, with Istanbul as its capital. ${ }^{2}$ It should be noted that this idea initiated by the Orthodox Church was soon reflected in the Balkans, where the Serbian autocephalous church ruled with influence for two centuries. In this context, among the first drafters of Pan-Slavic projects were: Adam Çartorijski and Franjo Zah ${ }^{3}$. Through these projects,

1 The Orthodox Slavs, after the weakening of the Empire of Napoleon Bonaparte, as well as after the promotion of the idea "America for the Americans" of the American President James Monroe (28.04.175804.07.1831), in 1823, began to think about the realization of the idea of uniting all Slavs in one state.

Hakif Bajrami, Si e okupoi Serbia Kosovën më 1912 (How Serbia occupied Kosovo in 1912), first part, Pristina, "Shkrola", 2003, 4 (hereinafter: Bajrami, How Serbia occupied Kosovo ).

3 Adam Jerzy Czartoryski (1770-1861) was a Polish immigration leader, writer and politician. While he was living in Russia, he was the Minister of Foreign Affairs of Russia (1803-1806). He is considered the inventor and referent of Garashanin in the drafting of Nachertania. He had also prepared a memorandum to the Russian king, according to which he foresaw the settlement of the Balkans after the destruction of the Ottoman Empire. Franjo Zah (1807-1892) is among the founders of the Serbian Military Academy. He was the first Serbian general. He had a crucial role in the drafting of "Nachertania" by Ilia Garashanini. He was the organizer of the first Panslavist Congress, held in 1848 in Prague. For more see: Ayşe Özkan, Miloştan Milin’a Sirp Bağimsizliği (1830-1878), (Nga Milloshi tek Millani Pavarësia e Serbisë), IQ Kültür 
the "concentration of the Balkan Slavs in a pan-Slavic Empire" was planned by categorizing the development of events into two phases. ${ }^{4}$ In the first phase, the war had to occur, while in the second phase, the ground had to be cleared so that living space for the Slavs was created. It should also be noted that in addition to the Slavs, many other people lived in these territories. ${ }^{5}$

Regarding the methods, the form of the rise and development of Pan-Slavic ideas, studies had been done by political scientists, clergies, Slavic scholars, and so forth, and the theses over which the Pan-Slavic Empire should rule were established. One of them was based on racism, compiled in the most detailed forms, categorizing the nations under the imaginary empire according to their anthropological development. ${ }^{6}$

It is worth noting that these methods and forms for creating the Pan-Slavic Empire were executed strictly by the Serbian Autocephalous Church on the nations in the Balkans, especially on the Albanians. In this regard, special programs were also compiled, which by order of the government, in cooperation with the church, had been implemented by the state army in most cases.

Viewed in historical retrospect, Albanians during the nineteenth century faced orthodox political calls for the creation of a state in the territories of the former Serbian king Tsar Dushani (1331-1355), with clear goals for a Greater Serbia (all Slavs in a state) for all southern Slavs, where Serbia would play a leading role. ${ }^{7}$ Albanians were subject to denial of everything non-Serb and to the call "Wherever there is a single Serb, the Serbian state must take its place."

Based on these Serbian policies, there were campaigns for the expulsion of Albanians from their lands, such as during the years $1800-1875$ on the occasion of the capture of the Paschal of Belgrade, and in 1868 when the campaign for the capture of the Sandzak of Nis took place, then that of the Vilayet of Kosovo, as well as before and after the decisions of the Congress of Berlin

Sanat Yayınctlk, Stamboll, 2011, 86-87; Rexhep Qosja, Shpërngulja e shqiptarëve sipas programeve kombëtare serbe, Tiranë, "Toena", 2005, 3-5 (hereinafter: Qosja, Shpërngulja e shqiptarëve); Niksa Stançiç, "Problem "Nacertanija" Ilije Garasanina u našoj historiografije, Historijski Zbornik", godine XXI-XXII, 1968, Povijesno drustvo Hrvatske, Zagreb, 142. (hereinafter: Niksa, Problem "Natcertanije"); "Ceh u sluzhbi serbije", Politika online, January 11, 2014.

4 Bajrami, Si e okupoj Serbia Kosovën, 11; www.politika.rs/rubrike/Svet/t27517.lt.html; "Ceh u sluzhbi Serbije”, Politika online, retrieved on January 11, 2014.

5 Kemal H. Karpat, Popullsia Osmane 1830-1914 Karakteristikat demografike dhe shoqërore, Tirana, Alsar 2017, 23, Popullsia e territoreve ballkanike, 1831. Muslim (Turkish, Albanian, Bosnian, tolerant, Pomak), Christian (Greek ( excluding Greece), Slavs, Albanians, Vlachs, Others (Jews, Armenians, etc.).

6 For more see, Niksa Stançiç, "Problem "Nacertanija" Ilije Garasanina unasoj historiografije”, ,'Historijski Zbornik", godine XXI-XXII, 1968, Povijesno drustvo Hrvatske, Zagreb.

$7 \quad$ Niksa, Problem "Natcertanije," 192; Serbia's foreign policy program for the occupation and colonization of Albanian territories was elaborated in "Naçertanie" (1844) by Ilia Garashanin (1816-1879), politician and later Prime Minister of the Government of the Principality of Serbia (he had led several ministries in governments of the Obrenovic and Karadjordjevic dynasties). The content of "Naçertanies " supported the creation of the so-called Southern Serbia, which meant Kosovo and Macedonia with its Albanian lands, also northern Albania, to create the so-called "Empire of Tsar Dushan."

8 While Garasanin in his project "Naçertanie" spread the idea of the Great Serbia, Vuk Karadzic in his 1849 article "Serbë të gjithë dhe gjithkund" (Srbi svi The Svuda) with a default nationalist language supported Garahananin and called for the denial of everything non- Serb in the countries around Serbia. He shouted and proclaimed: "Wherever there is a single Serb, the Serbian state must take its place"; Bejtullah Destani, Muhaxhirët (Dosja Britanike, spastrimi etnik i Toplicës, Nishit, Prokuplës, Kurshumlisë, Leskovci, Vranjës 1878-1884, Prishtina, “Artini,” 2019, 232-236, 268. 
(1877-1878). During this time, terrible anti-human action occurred. ${ }^{9}$

Subsequently, after the occupation of the Vilayet of Kosovo, genocidal actions were taken by the Serbian and Montenegrin regions; demolition and burning of houses, harassment, murder and liquidation of innocent citizens. All this in order to displace Albanians and colonize Kosovo with Serbs.

\section{The colonial, agrarian and cleansing policy in Kosovo (1912-1945)}

Even in the early years of the XX century, Albanians were systematically confronted with new Serb programs, which went to extremes, wanting to destroy an entire nation. ${ }^{10}$ The Serbian regime pursued a hegemonic and destructive policy towards the Albanians. They burned the villages, massacred the population, looted the means and the property of the Albanians. In his platform regarding Kosovo and the Albanians during the years 1912-1915, Ilia Garashanin presented his basic thesis in what can be considered a purely chauvinist project titled "Naçertania", he presented a key principle: "Serbization at any cost". In this context, the Serbian Police Inspector in Skopje, Mihailo Ceroviç, threatened the Albanians that he "will cut off their legs and heads if they do not become Serbs". The aim of the Serbian policy in Kosovo was the political and economic oppression of the Albanians, to expel them from their homeland, Kosovo, and to establish a Serb colony, in order to realize this platform. ${ }^{11}$ Through calls, the Serbian government openly demanded in front of the then-international-opinion that the Albanians be liquidated as the nations of North Africa were liquidated. ${ }^{12}$ Above all, they managed to justify themselves and be accepted in the eyes

9 From 1800 to 1875 , about 150,000 Albanians were expelled from the Pashallëk of Belgrade, Shaban Braha, Idriz Seferi in the Albanian National Movement, Tirana, 1982, 23. Only from the Sandzak of Nis in only three days 620 villages were forcibly cleansed. Jenes Reuter, Shqiptarët në Jugoslavi, translated by Nestor Nepravishta, Tirana, "Impex", 19; Muhamet Pirraku : Myderiz Ymer Prizreni, Prishtina, "Koha", 2003, 60 (hereinafter : Pirraku, Myderiz ); Jusuf Osmani: "Kolonizimi serb i Kosovës", Prishtina, 2000, 55 (hereinafter: Osmani, Kolonizimi Serb) . More than 700 Albanian settlements were cleaned, with over 200,000 deported and settled mainly in the present-day territories of Kosovo, but also their large-scale displacement in the present-day territories of Turkey. For more see Sabit Uka, Dëbimi i shqiptarëve nga Sanxhaku i Nishit, 1877/78, Prishtina, I, 1994 . However, it should be noted that Vuk Karadzic's 1849 project, "Serbë të gjithë dhe gjithkund" (Serbian svi i svuda), as well as that of Milutin Garasanin's in 1885 , "Ndikimi i Serbisë në Maqedoni dhe Kosovë", were references to undertaking genocidal actions both before 1877 and thereafter.

10 In 1902, Nikola Stanojevi drafted the project "Deri në shfarosjen tuaj ose tonën”, while the Government of Serbia, during the years 1908-1912, announced the new extensive Serbian program entitled: "Direktiva për punë me shqiptarët" (Directive for rad sa Arnautima). In 1910, Nikola Pashiqi drafted the elaboration "Çka do Serbia" (Sta hoç Serbija), while during the years 1906-1913, Jovan Cvijiq in his project "Çështja e Shqipërisë Veriore" (Pitanje Severne Albanije), justified the penetration of the Serbian state in the Adriatic Sea.

11 Fitim Rifati, Kosova gjatë Luftës së Parë Botërore 1914-1918, Prishtinë: Instituti i Historisë - Prishtinë, 2019, 37-38.

12 Vladan Gjorgjeviq, Arnauti i Velike Sile, Beograd, 1913, 1-188 (më tej: Gjorgjeviq, Arnauti) Arnauti $i$ Velike Sile is a program that is presented to the European public through an 188-page pamphlet. The Serbian government claimed to obtain the permit for the liquidation of Albanians, published in several languages and with it "proved" that "Albanians do not have the language, do not have their own books (literature), do not have their own history, according to the Serb orientations (programs) Albanians do not have the right to life, they do not have the right to exist, they do not have the right to form any state." Not only that, the Minister of Foreign Affairs of the Kingdom of Serbia would clearly demand in Vienna 
of the powers of the time, especially in the London conference (1912-1913), where they managed to extend their rule over the occupied Albanian lands. ${ }^{13}$

During this time the Serbian nationalist imagination goes beyond reason and human belief "Several generations of Albanians must die to forget what the Serbs did to them." 14 With this idea from 1912 to the end of 1913 over 120,000 Albanians were executed in various forms, and about 50,000 others moved towards Turkey. ${ }^{15}$ Additionally, by Serbian and Montenegrin forces 235 Albanian villages were completely burned from 1912 to $1914 .{ }^{16}$ During this time (1912-1915), as in the Sandzak of Nis, in 1878, after the departure of the Albanians from Kosovo, began the colonization of Albanian lands with the Slavic element. ${ }^{17}$

This anti-Albanian policy had continued even after the end of the First World War, when Kosovo was reconquered by the army of the Serbo-Croatian-Slovenian Kingdom, which did not reduce the violence against Kosovo Albanians, ${ }^{18}$ but continued their annihilation without interruption and with a constant rhythm ${ }^{19}$. Thus, between the two world wars, under constant pressure, the Albanian nation faced the idea of dismantling the Albanian nation in the Balkan way "through imprisonment, violence and murder, adding the psychosis of fear in every aspect, for the final solution of this issue." ${ }^{20}$ Moreover, as a result of these repressive measures during this time began the expulsion of Albanians to Turkey. ${ }^{21}$

that the Albanians "be liquidated as the nations of North Africa have been liquidated."

13 Since the occupation of Kosovo in 1912, and the sanctioning of this occupation by the Great Powers at the Conference of Ambassadors in London in 1913, Albanians have been subjected to continuous persecution, denial and abuse of their basic human and national rights. According to the decisions of this Conference, out of $90,270 \mathrm{~km} 2$, only $28,500 \mathrm{~km} 2$ was included in the Albanian state. Outside the Albanian state remained the territories of the Vilayet of Kosovo, Shkodra, Bitola and Ioannina.

14 For more see the 1910 elaboration of Nikola Pashiqi: "Çka dëshiron Serbia" (Sta Hoçe Serbija), Riza Lahu: Golgota shqiptare, Tirana, 1995, 43-44 .

15 Fitim Rifati, Kosova gjatë Luftës së Parë Botërore 1914-1918, Prishtinë: Instituti i Historisë - Prishtinë, 2019, 43.

16 Hakif Bajrami, Politika e shfarosjes së shqiptarëve dhe kolonizimi serb I Kosovës (1844-1945), Prishtina, 1995, 17.

17 On March 5, 1914, the Government of Serbia issued the "Dekretin mbi kolonizimin e viseve të posaçliruara dhe të bashkuara në Mbretnin e Serbisë", while Montenegro, on March 12, 1914, issued the "Ligjin mbi kolonizimin e viseve të posaçliruara". Ongoing projects (between the two world wars) are that of Stojan Proti of 1920, "Problemi Shqiptar" (The Albanian Problem), that of Vasa Çubrilloviqit of March 7, 1937 "Shpërngulja e Arnautëve" (Iselevanje arnauta), and the study of Ivo Andric, "Mbi çështjen shqiptare."

18 Neol Malcom, Kosova një histori e shkurtër, Second Edition, translated from English by Abdullah Kajragdiu, Prishtina, "Koha", 2001, 284, (hereinafter : Malcom, Kosova një histori). Serb troops in Kosovo during January and February 1919 alone had killed 6,040 people, had destroyed 3,873 houses. Malcom , Kosova një histori , 289,... A document drafted by the Kosovo Committee in 1921 estimated that 12,371 people had been killed, 22,110 imprisoned, and approximately 6,000 houses burned.

19 Hakif Bajrami, Peticioni që i shpëtoi shqiptarët në Shqipërinë Kontinentale nga fashizmi serb, „Shkrola” Prishtinë, 2005, 2; Emine Bakalli, Përpjekjet e Komitetit "MKK” për denoncimin e dhunës dhe mbrojtjen e të drejtave kombëtare e demokratike të shqiptarëve në Jugosllavi, in a summary of papers, Komiteti Mbrojtja Kombëtare e Kosovës, Academy of Sciences, Tirana, 2004, 35.

20 For more see: Vasa Çubrilloviq, Shpërngulja e Arnautëve, March 7,1937; Pajazit Nushi, Krimet e Gjenocidit të Serbisë ndaj shqiptarëve në Kosovë, KMDLJN, Prishtina, "BULETINI", no. 14, JanuaryMarch 2000, 18. For more also see: Qosja, Shpërngulja e shqiptarëve, 5-13.

21 The Yugoslav - Turkish Convention of 1938. This convention was preceded by talks between the two 
The unceasing pressure was exerted on the idea of the state, which planned the partition of Albania between Italy and Yugoslavia, and provided for areas of interest, the assimilation of Albanians of the Catholic religion and the partition of the Albanian state. ${ }^{22}$ There were also ideas for the partition of Albania between Serbia and Greece, leaving aside Italy, for which it was planned that the Albanian people should be subjected to the most rude methods and forms that could be thought of. ${ }^{23}$

The Albanian nation of Kosovo, despite participating in the Second World War alongside anti-fascist nations and states, despite relying on the decisions and principles of international conferences of the Atlantic, Moscow and Tehran, were under the constant threat of extinction. ${ }^{24}$ The best indicator of the situation in which the Albanians found themselves is the saying used

governments in 1935. The Turkish government was represented by Foreign Minister Ruzhdi Arasi, while that of the Yugoslav Kingdom by Prime Minister Milan Stojadinovic. Stojadinovic had founded the socalled "Serbian Cultural Club" (1937). Through this, the Serbs' intention to annihilate Albanians were openly shown through three final methods: 1. Burn all Albanian settlements, 2. Colonization, leaving Albanians 0.40 hectares of arable land only, favoring the Slavs by enabling the possession of 45 hectares of arable land and 3. Eviction in Anatolia. This covenant had to do with population figures that were displaced. It was planned to relocate 40,000 Albanian families. The relocation was scheduled to begin in 1938 and to be completed in 1944. Under this plan, 4,000 families were planned to relocate in 1939, of which 6000 families were scheduled to relocate by 1940, 7000 families were scheduled to relocate during 1941 and 1942 as well as 8,000 families during 1943 and 1944. The governing body for displacement was the Committee, within which the Supreme Inspectorate for Displacement based in Skopje functioned. The Yugoslav government did not want Albanians to move to Albania, due to the increasing number of residents in Albania and entry of an item, which was hostile to Serbs. Serbia wanted the Albanians to reside as far away from their homeland as possible, in the deserts of Anatolia, having no contact with their country and unable to ever return to their homeland.

22 Ivo Andric (1892-1975), Serb from Bosnia and Herzegovina, diplomat in the time of the Serbo-CroatianSlovenian Kingdom, writer (Nobel Laureate in Literature in 1961). During the years 1937-1939, Andric was Deputy Minister of Foreign Affairs in the royal government of Milan Stojadinovic. The head of the SKS royal government, Stojadinovic, had engaged Andric to compile an official memorandum (Aide Memoire) on the Albanian issue, for the internal needs of the Ministry of Foreign Affairs. Andric finished the official reminder (Aide Memoire), on 30 January 1939. In January 1939, after a visit that the Minister of Foreign Affairs of Italy, Galeazzo Canon, made in Belgrade and after having had a meeting with the head of the royal government Stojadinovic (where the topic of discussion was also the Albanian issue), the latter had engaged Andric in a project related to the Albanian issue for the internal needs of the Ministry of Foreign Affairs. It was first published by the Croatian historian Bogdan Krizman in 1977 in "Časopis za suvremenu povijest" (Journal of Contemporary History), entitled "Elaborati i dr. Ivo Andriqit për Shqipërinë i vitit 1939". In Serbia, this document was first published in 1988 in the magazine "Sveske", Andric's Fund. This report was published in Albanian in 1981, translated by Jusuf Gërvalla in the newspaper "Zëri i Kosovës" which was published in the diaspora and which was distributed illegally in Kosovo and other Albanian lands. Unlike Ivo Andric, Ivan Vukotic (senior official in the Minister of Foreign Affairs of Yugoslavia), in his project, among other things, would add that the unification of Northern Albania and a part of Central Albania "is a vital interest of our people, the realization of our natural aspirations and the fulfillment of our centuries-old desires

23 The beginning of the Second World War was an obstacle in realizing these horrifying plans upon the Albanians. International call for joint struggle against fascism, especially the call of the Communist Party of Yugoslavia (CPY), which upon having received the blessing for leading the fight in Albanian areas ("war which will be concluded with respect to self-determination"), Albanians despite distrust of political rule and Serb-Yugoslav organization responded to it by finding the power of faith and a combined organization in this war, by leaving aside but never forgetting the bitter past.

24 Atlantic Conference, Riviera in Argentina 9-12 August 1941, Moscow 18 October-1 November 1943 and Tehran 28 November-1 December 1943. 
by Serbian leaders "There will not be a single fez left in Kosovo", alluding to the complete extermination of the Albanian nation. ${ }^{25}$ In these circumstances of the Second World War, Kosovo Albanians found themselves in difficult, unjust and hopeless situations for the realization of their aspirations for freedom and self-determination. This was best observed with the reaction of the war governing bodies and the leaders of the Communist Party of Yugoslavia after the decisions of the National Liberation Conference for Kosovo and the Dukagjini Plain, which was held in Bujan. ${ }^{26}$ Such situations and circumstances influenced the Albanian patriots at certain moments to divide and begin planning the solution of the national issue in other forms.

During the end of the war, September 1944 - July 1945, the Albanian people of Kosovo experienced one of the most severe sufferings in their history. In addition to the establishment of the Military Administration in Kosovo, on the grounds of the leadership of the Communist Party of Yugoslavia (CPY), allegedly obstructing and paralyzing "counter-revolutionary" forces, the Albanian people of Kosovo were subject to the re-emergence of fascist ideas from intellectuals about ethnic cleansing. ${ }^{27}$ The years 1944-1945 were an indication and a reminder of the earlier times that plans of the Great Serbia were in power and that they were also supported by the new Yugoslav government of that time. ${ }^{28}$ These anti-Albanian chauvinist actions were hidden by the Yugoslav communists behind the slogans of brotherhood-union, equality of nations and internationalism, a chauvinism that erupted as savage and cruel as in earlier periods. ${ }^{29}$

\section{Serbian Ultra Nationalism after World War II (1945-1989)}

Systematic pressures on Albanians displaced from Kosovo continued even after World War II. The pressures were of various kinds. They were realized through state and interstate agreements. One such agreement is that of February 18, 1953, of mutual cooperation between Yugoslavia, Greece and Turkey, as well as that between the President of Yugoslavia, Josip Broz Tito, and the Turkish

25 Stevan Moleviiq, in 1941 drafted a political project called "Homogeneous Serbia". The realization of this policy, the project, was seen as possible through the massacre of all Albanians and Muslims. Followers of Molevic's idea declared: "There will not be a single plis left in Kosovo." The Chetnik leader Draza Mihajlovic in 1942 devised a similar program for the expulsion of all Muslims from the Balkans.

26 Lefter Nosi, Ripushtimi i Kosovë, September 1944 - July 1945, Tirana, „Tirana”, 1994, 138. Muhamet Shatri, Kosova në Luftën e Dytë Botërore, ”Dukagjini”, Peja, 1997, 142.

27 Vasa Çubriloviq, Manjinski problem u novoj Jugoslaviji, 3 November 1944, 385-389,

28 On November 3, 1944, Vasa Çubriloviq, designed the project "The problem of minorities in the new Yugoslavia" ( Manjinski problem u novoj Jugoslaviji), a complement to the year 1937. The project elaboration foresaw the disappearance of all means of Albanians in Yugoslavia. V. Çubriloviq, before the top leadership of the the national liberation war of Yugoslavia and the National Liberation Army, proposes the mass displacement of millions of people, because, according to him, "the only and just solution to this issue is the displacement of these minorities." As support and example for such an action he took the actions of the Third Reich and the expulsions and colonizations of many nations in the Soviet Union and other European countries. The author of the project also provided details for the realization of this project. For the realization of the project,V. Çubriloviq foresaw the time, means and ways of action. According to him, the most appropriate time for efficient displacement was war, so the most successful displacement was the physical and complete extermination of people. According to Çubriloviq, The army had a crucial role, so he proposed that a special section on this issue be formed at the UNJ Headquarters.

29 After the war, this policy and these measures were justified and presented as actions directed against "reactionary Albanians", "counter-revolutionaries", "collaborators of the occupier", "bandits", etc. 
President, Fuad Kyperli, reached in Split, Croatia, known as the "Gentlemen's Agreement" ${ }^{30}$. With this agreement, the Agreement of 1938 was restored to force. This agreement was signed in great confidence and J. B. Tito hired Aleksandar Rankovi for its realization. Yugoslavia, through J. B. Tito, once again expelled in the most brutal form the Albanians from all the areas where they lived. According to this agreement, until 1967, 41,200 Albanians were displaced. ${ }^{31}$ According to scholars in this field, during this time Kosovo continued to be colonized by a large number of Serbs and Montenegrins, for which the Serbian state had taken legal action regarding the possibility of implementing colonization and agrarian reform. ${ }^{32}$ The colonizers were from different parts of Yugoslavia and were mostly professionals in various fields and relatives. ${ }^{33}$ All were employed mainly in state and cultural organizations and institutions, etc. It is estimated that from 1945 to $1965,12,300$ Slavic families settled in Kosovo, or about 64,000 people of Slavic descent. ${ }^{34}$

The years 1966-1981, especially those after the adoption of the 1974 Constitution, were a ray of hope for Kosovo Albanians. Many scholars would consider those years as the most successful years for Kosovo Albanians in all areas of life; political, social, cultural and economic. However, despite that the Albanians managed to be the bearers of some institutions through the constitution, Serbs and Montenegrins were experiencing all the benefits. ${ }^{35}$ Such a situation of advancement of the Albanian people did not suit the nationalist forces of the Slavic ranks who began to declare in front of their public that Serbia was losing in freedom what it had won in the war, and other anti-Albanian slogans. All this was propagated to argue that Serbian rights were being violated, so Serbian politicians began to demand a review of the status of the autonomous provinces. ${ }^{36}$ During these years, anti-Albanian circles began to fabricate a political character of "pressure for displacement" on Serb and Montenegrin citizens in Kosovo, which was a serious slander on which

30 Hakif Bajrami, Naçertania Program politik serb që shpie në shfarosjen e shqiptarëve 1844-1999, „Shkrola”, Prishtina, 2004, 219, Ramadan Xhema, Nuk mposhtet shqiptari, Prishtinë, 2004, 384.

31 Bajrami, Naçërtania Program politik, 218; Pajazit Nushit, "Krimet e gjenocidit të Serbisë ndaj shqiptarëve në Kosovë”, KMDLJN, Prishtina, BULETINI, no. 14, January - March, 2000, page 21.

32 It should be mentioned that together with the agrarian reform and colonization, other laws were approves, such as; Law on Revision of Land Allocation to Colonists and Agrarian Stakeholders in Macedonia and the Province of Kosovo and Metohija, Law on Agrarian Reform and Colonization, Law on Allocation of Abandoned Lands of Settlers in the KAKM and Law on Agrarian Reform and Internal Colonization.

33 On the grounds that the property of the enemies of the people is being confiscated and the decision of the highest state bodies on the transfer of state ownership of the property of the enemies, then the Law on the transfer of ownership of the property of the enemies, etc.

34 Jusuf Osmani, Kolonizimi serb i Kosovës, Prishtina: ERA 2010, 159 . (hereinafter: Osmani, Kolonizimi Serb). The displacement of Albanians from Kosovo became widespread with high intensity, especially during the ' 50 s and' 60 s of the twentieth century. During these years 283,000 Albanians moved to Turkey, which means close to a third of the population at that time. KMDLJN, Prishtina, BULLETIN, no. 14, January-March 2000, p. 21.

35 According to the Kosovo Statistics Office, the national population structure in 1981 was: Albanians $77.4 \%$, Serbs $13.2 \%$, Montenegrins $1.7 \%$ and Turks $0.8 \%$. Whereas according to the data from the employment office, on 30. IX 1988 were employed: 162,499 Albanians, 51,092 Serbs, 6,957 Montenegrins and 3,014 Turks. From this it can be seen that in the mentioned year every third Montenegrin, every fifth Serb, and every thirteenth Albanian were employed.

36 In 1977, Serbian "intellectuals" drafted the "Blue Book". After the adoption of the constitution of 1974, the leaders of the Republic of Serbia opened constitutional issues by contesting the constitutional position of the autonomous provinces. Among other things, the "Blue Book" emphasized that the rights and competencies of the autonomous provinces should be limited. 
strategic anti-Albanian projects were created. According to Serbian sources, from 1967-1980 57,118 Serbs were displaced from Kosovo. ${ }^{37}$ The Serbo-Yugoslav government took advantage of this anti-Albanian climate and began militarizing Kosovo in the early 1980s, especially after the 1981 demonstrations. ${ }^{38}$ By the year 1981, actions were taken of various purposes with immediate deadlines for them to change the ethnic structure in Kosovo. To achieve this goal, the Serbian government did not hesitate tofabricate various political processes and other oppression of Albanians, on the other hand, justified all actions with "injustices" done to Serbs and by the nationalist and separatist intentions of the Albanians. ${ }^{39}$ The Serbian regime, supported by the Yugoslav one, taking advantage of this anti-Albanian climate began to approve assessments, platforms, resolutions and programs ostensibly for the return of Serbs and Montenegrins to Kosovo, while in fact, another wave of colonization (recolonization) of Kosovo with the Slavic element was being prepared..$^{40}$ In the context of this anti-Albanian climate, the Academy of Sciences and Arts of Serbia (ASAS) in 1986 drafted a Memorandum of Understanding. ${ }^{41}$ The memorandum was a strategic document of the Serbian intelligence, which set out the direction of "resolving" the Serbian issue within the former SFR Yugoslavia. In essence, the Memorandum contained the "ideology of a Greater Serbia." According to the Memorandum, the borders of Serbia were not in line with the ethnic composition and, as such, they should have been corrected considering that the 1974 Constitution had damaged Serbia due to the creation of the autonomous provinces of Vojvodina and Kosovo, the weakening of the Federation and because it created "artificial" administrative boundaries, which did not reflect a "real" picture. ${ }^{42}$

Subsequently, the Memorandum of Understanding had a decisive impact on the development and renewal of the nationalist movement in Serbia, initially within the Communist League of Serbia. The memorandum directly influenced, or rather was a reference to the Serbian nationalists led by the head of state Slobodan Milosevic, who tried to realize the ideas presented in the memorandum

37 Osmani, Kolonizimi serb, 160.

38 “Zëri i Kosovës”, Organ i Lëvizjes Popullore për Republikën e Kosovës, Year VIII, no. March 3, 1989, 3 .

39 Based on the sources of the time, in order to extinguish the freedom-loving voice of the Albanian people, the Yugoslav-backed Serbian regime, from 1981 until 1985, had sentenced about 4,000 people. Until the reconquest of Kosovo in 1989, 183 civilians and about 100 Albanian soldiers in the Yugoslav army were killed in numerous demonstrations. 1,346 soldiers and 10,000 civilians were convicted of political offenses. 3,500 people have served an average sentence of 7.1 years in prison. Every third Albanian in Kosovo has been mistreated by the police. For more see, Ethem Çeku, Shekulli i Ilegales-Proceset gjygjësore kundër ilegales në Kosovë, Dokumente, Prishtina, "Brezi 81”, Prishtina 2004. Jakup Krasniqi, Pranvera e lirisë'81, Prishtina, "Buzuku", 2011.

Osmani, Kolonizimi serb, 161.2

41 Grupa Akademika Srpske Akademije Nauka i Umetnosti, Memorandum o Aktuelnim društvenim pitanjima u Jugoslaviji, Beograd,1986. The idea for the text of the "Memorandum" was accepted in the assembly of ASHAS on May 23, 1985 and for its compilation the following academics were proposed: Pavle Iviq, Antonije Isakoviq, Dushan Kanazir, Mihajlo Markoviq, Milos Macura, Dejan Medakoviq, Miroslav Pantiq, Nikola Pantiq, Ljubisa Rakiq, Radovan Samardziq, Miomir Vukobratoviq, Vasilije Krestiq, Ivan Maksimoviq, Kosta Mihajloviq dhe Stojan Celiq. This document was published for the public in two sequels, through the Serbian newspaper 'Vecernje Novosti', on 24 and 25 September 1986.

42 Alfred Beka, Memorandumi i Mirëkuptimit, newspaper"Ekspres", Prishtina, dt. 11.01.2014; Grupa Akademika Srpske Akademije Nauka i Umetnosti ,Memorandum o Aktuelnim društvenim pitanjima u Jugoslaviji”, Beograd,1986. 
through the idea of a Greater Serbia, which in the meantime caused the wars and numerous tragedies in Slovenia, Croatia, Bosnia and Herzegovina, and Kosovo. ${ }^{43}$

The official policy of Serbia, based on the Memorandum of the Serbian Academy of Sciences and Arts (SANU) of 1986, by the end of 1987 until 1989 organized debates for the beginning of constitutional changes, which provided for the reduction of the rights of the two Autonomous Provinces within Serbia, The Federation of Yugoslavia, respectively the Socialist Autonomous Province of Kosovo and the Socialist Autonomous Province of Vojvodina. ${ }^{44}$ During these debates there were various anti-Albanian calls, which were organized in both Kosovo and Serbia, where the main calls were: "Kosovo is Serbia!", "Kosovo is the heart of Serbia", "Kosovo is a sacred Serbian land!", "We will fight for this place of the old Serbian land", "Serbia, do not let Kosovo leave your grasp!", etc. ${ }^{45}$ Serbian leaders, such as Ivan Stambolic, were heard shouting: "Do not allow them to consider Kosovo their own, it is a mine for Yugoslavia, do not allow Kosovo to secede, as it is Yugoslav territory." ${ }^{46}$ After numerous rallies and debates, under the pressure of numerous police forces, which were extraordinary measures, on March 23, 1989, the next meeting of the Assembly of Kosovo began. ${ }^{47}$

The main item on the agenda was the adoption of draft amendments proposed by Serbia, which provided for the acquisition of many competencies to the institutions of the Socialist Autonomous Province of Kosovo (SAPK) ${ }^{48}$ Following the approval by the Assembly of Kosovo of the draft amendments proposed by Serbia, on 28 March 1989 in Belgrade, the Federal Assembly of Yugoslavia, in an extraordinary and solemn session, approved the draft amendments, with the 47th amendment abolishing the Autonomy of Kosovo, which was provided for by the 1974 Constitution.

43 Alfred Beka, Memorandumi i Mirëkuptimit, newspaper"Ekspres”, Prishtinë, dt. 11.01.2014, Grupa Akademika Srpske Akademije Nauka i Umetnosti „Memorandum o Aktuelnim društvenim pitanjima u Jugoslaviji”, Beograd,1986; For more also see: Qosja, Shpërngulja e shqiptarëve, 210-275.

44 On October 24, 1987, the Presidency of the SFRY declared a state of emergency in Kosovo. The state of emergency was imposed following the constant demands of Serbian political leaders and Serbian demonstrators. The anti-Albanian demonstrations consistently called for: "Albanians must be killed", "We cannot live with Albanians", "All Albanians are enemies of Yugoslavia", "We want weapons", "We want a military administration", "Kosovo is Serbia", "Kosovo is Serbian and not Albanian ", Albanians in Albania, Serbs in Serbia, Turks in Turkey ", We want freedom ", We have not had freedom for 40 years ", etc. To give a special, more "touching" and more "sentimental" tone to all the "suffering from the pressure of the Albanians", Belgrade organized a series of demonstrations held by Serbian and Montenegrin women in Pristina, Fushë Kosovë, Lipjan, Suhadoll, Vitomorica, Caglavica, Babin Most, Gjilan and Prilluzha. Such demonstrations were triggered by a statement by Fadil Hoxha on SerboMontenegrin women. "Zëri i Kosovës", Organ i Lëvizjes Popullore për Republikën e Kosovës, Year 6, Nr. October 10, 1. and Nr. November 11, 1987, 1 - 2.

45 Daily reports and statements broadcast in all print and electronic media of the time.

46 Daily newspaper "Politika", April 8, 1986, Belgrade.

47 On 28 February 1989, the Presidency of the Socialist Federal Republic of Yugoslavia (SFRY), at the request of Serbia, applied violent measures in Kosovo, as in 1945, 1968, 1981. Kosovo was occupied.

48 Esat Stavileci, Pavarësia e Shqipërisë dhe Kosova 100 vjet pas, excerpts from the speech delivered at the Conference organized by KASA, on September 13, 2012. 


\section{Serbian Reoccupation of Kosovo, 28 March 1989-12 June 1999}

After the abolition of Kosovo's autonomy, the Serbian government planned to restore the ethnic balance in Kosovo, terrorizing the Albanians to leave their homes, and in their place to bring Serbs and Montenegrins in order to slavify and colonize Kosovo. In this regard, by the Serbian government's request, on February 9, 1990, the Yugoslav Assembly adopted the "Yugoslav Program for Kosovo." The program planned to take measures in all areas, such as; political, economic, cultural, educational, health, judicial, informational, employment, übanism, demographic development, etc. "The Program for the Realization of Peace, Freedom, Equality and Prosperity of Kosovo", known as "The Program for Kosovo", was simply a discriminatory and racist program against the Albanian people. ${ }^{49}$ It provided for the creation of new jobs, employment advantages, special incentives for investment in employment programs, all of this was done for the arrival of a larger number of Serbs and Montenegrins to live and work in Kosovo as well as prevent any future relocation from Kosovo. It is foreseen to have reduced all Albanian cadres in social institutions and economic organizations. ${ }^{50}$ It provided for the issuance of a special law, which would establish a fund for the provision of material conditions for the development of Kosovo, in order to prevent the displacement of Serbs and Montenegrins, and the return and arrival of young people.

In terms of plans for the establishment of Slavs in Kosovo, the Serbian regime had drawn up one for the entire territory of Kosovo, which amongst other plans envisaged the construction of neighborhoods specifically for this colonization. In addition to creating these new neighborhoods, many tourist and hotel facilities during this time were occupied and turned into housing units for settlers from different countries. ${ }^{51}$

In the framework of fulfilling the "Program for Kosovo", the Assembly of the SFRY on February 16, 1990 had approved the "Law on the provision of housing for the needs of staff and the return of persons displaced from Kosovo in the period 1989 to 1993". It had also issued the "Law on the implementation of that program."

Another step in Serbia's pan-Slavic journey was the allocation of lands to settlers as well as the creation of funds to cover ongoing costs. ${ }^{52}$

49 In March 1990 over 7,000 Albanian pupils were poisoned; Kohavision, the show "Today", chronicle of researcher / journalist Ardiana Shala: "Helmimet masive të 90-ës: krimi që nuk u dënua kurrë”, May 2018.

50 “Zëri i Kosovës”, Organ i Lëvizjes Popullore për Republikën e Kosovës, Year X, no. 6 April, 1991, p. 13 , Over 35000 different Albanian workers and cadres had been fired and in the most profitable enterprises were imposed violent measures by Serbian and Montenegrin directors and leaders. The university clinics and the Faculty of Medicine in Prishtina, by decision of the Assembly of Serbia, were occupied by the Serbian police on 8 August. A total of 1167 workers were fired, ranging from university professors to administrative and technical clerks . On September 27, 1990, the staff and management of the People's and University Library of Kosovo were forcibly fired. The violent organs of the Serbian regime had announced the disappearance of funds for literature in the Albanian language. Serbian police had taken control of all posts in Kosovo, about 1,500 Albanian workers had been laid off. All Albanian police officers, about 4,000, as well as a considerable number of judges and prosecutors were fired and replaced by Serbs and Montenegrins.

51 Osmani, Kolonizimi serb, In December 1991, in order to recolonize Kosovo, 100 Serb and Montenegrin families fleeing Albania settled in the premises of a children's and youth resort in Deçan.

52 On March 8, 1990, the "Law on the Revision of the Allocation of Land to Settlers in Kosovo and 
The Serbian government showed extreme determination against the Albanians with another legal act: The Law on the Territorial Organization of Serbia, drafted on January 29, 1992. ${ }^{53}$ Through this law, the Serbian government paves the way for changing the names (toponyms) of

existing settlements, roads, institutions, social, cultural and educational, as well as the formation of new municipalities. ${ }^{54}$

According to this law, municipal assemblies are obliged to "reconsider the existing names of settlements and to appoint new names within one year from the day of its entry into force". This law, which provided for the change of the names of schools, streets, squares, various organizations, as well as their naming with Serbian names, is another proof of the Serbization of Kosovo. At this time Cyrillic writing began to dominate everywhere. This is a powerful indicator of the destructive policy plans of Milosevic and the entire Serbian state apparatus. The Serbian government, through the Slavicization of the autochthonous toponyms of the Albanians, wanted to lose the historical traces and everything which had Albanian roots in Kosovo. ${ }^{55}$

One of the Serbian programs that hit the Albanian population in Kosovo was the "Program for the formation of the fund for the development of Serbia". The program was approved on August 6, 1992. Based on this, funds were provided for the continuation of the campaign for the colonization of Kosovo with Serb populations from different parts of Yugoslavia, such as: Serbia, Bosnia, Croatia, Montenegro. ${ }^{56}$ In order to realize the development fund, Serbia adopted the Law on the Transformation of Socially-Owned Property into Private Property. According to this law, from the

Macedonia" and the "Law on the Establishment of a Fund for the Return of Serbs and Montenegrins to Kosovo" were adopted.. Dr. Hivzi Islami, Kosova dhe shqiptarët. Çështje demografike. Prishtinë, 1990, fq. 164.

53 The administrative division of Serbia, January 29, 1992, “Административна подела Србије , 29 January 1992 www.wikipedia.org/wiki, accessed 21 January 2014.

54 According to this law , new municipalities were formed, such as Zubin Potok, Zvecan, Shterpce and Gora. Administrative division of Serbia, January 29, 1992, “ Административна подела Србије , 29 January 1992" http://sr.wikipedia.org/wiki , and received on January 21, 2014.

55 The streets were named after medieval Serbian figures, such as Sveti Sava, Car Dushani, Stefan Dençan, Carica Milica, etc. instead of them being named after Albanian figures. For psychological effect, some streets and squares were named after cities in Serbia, Bosnia, such as Banja Luka, etc., or to symbolize the Serbo-Greek Orthodox alliance called "Athens". The Serbian government went so far as to provoke the feelings of the Albanians by naming some streets with the names of various collaborators, such as Sejdo Bajramovi, Rrahman Morina, etc. Not only that, what added to the provocation was naming several streets with names, such as "Serbian Warrior", "Serbian Insurgent", knowing that among Albanians these names are reminiscent of Chetnik violence.

56 Serbia 's law on the transformation of socially-owned property into private property provided that from the sale of socially-owned property it would allocate funds to the Serbia Development Fund, which apparently planned the colonization of Kosovo. In addition to the authorities, various organizations, people, and other associations provided various proposals for the colonization of Kosovo. A proposal was made to bring in 400,000 Serbs from Romania. Even the Israeli version of the colonization of Kosovo was considered, then there was the proposal that the colonization of Kosovo be done immediately, making Pristina the capital of Serbia and Yugoslavia, where all state institutions, military and police schools, many officers, clerks, police, etc., with family would be transferred to Pristina. This wave of colonization would reach a number of 100,000 Serbs until the request of some Kosovo Serb officials to immediately come to Kosovo at least 300,000 Serbs and Montenegrins . For more see Dr. Hivzi Islami, Kosova dhe shqiptarët. Çështje demografike. Prishtinë, 1990, fq. 173. 
sale of social property, $60 \%$ of the funds were allocated to the Development Fund of Serbia, which financed the colonization of Kosovo. In this context, increased attention was paid to the integration of Kosovar enterprises into Serbian ones, which destroyed family and state economies. ${ }^{57}$

Regarding Kosovo colonization other institutions contributed, among them the Association of Serbs and Montenegrins "Bozhur" from Fushe Kosova. This association projected the idea beyond the colonization campaign, demanding a ban on the activities of parties, associations and other associations that are being exposed "hostilely" in Kosovo, etc., as well as urgently requested the enactment of the law on family planning. ${ }^{58}$

The Serbian government was not satisfied with the fulfillment of the plans for changing the national structure of the people of Kosovo. The Serbian government increased the intensity of systematic terror against Albanians through the action of collecting weapons. The scenario was almost the same or identical to that of the 1950s , many families were raided, beaten, persecuted, arrested and convicted. ${ }^{59}$ The Serbian government was mainly oriented against young people, with the aim of encouraging displacement.

One of the forms of Serbian terror, aimed at pressuring the displacement of Albanians, was the action to collect weapons. ${ }^{60}$ Young people faced numerous provocations made by the police, the government, the administration and the Serb and Montenegrin population living and operating in Kosovo.

Always in the context of the colonization and Slavization of Kosovo, of the fulfillment of the pan-Slavic mission, after the dissolution of Yugoslavia, the Assembly of the so-called Federal Republic of Yugoslavia (FRY), on March 17, 1994, approved "The law on the provision of housing for the needs of cadres and the return of displaced people in Kosovo." According to this law, in the period from 1994 to 1998, 1,564 dwellings were built or purchased for these needs. In 1994 alone,

57 Daily newspaper "Rilindja”, Dhuna në ekonomi, Prishtinë,, Prishtina, dt. 19 October, 1992 , the Kosovo Chamber of Commerce had offered 219 Kosovar companies for integration into Serbian ones. The Institute of Metallurgy of Smederevo and Bor (cities in Serbia) prepared the documentation for the demolition of the "Ferronikel" of Drenas (Gllogovc). Theranda's "Balkans" were planned to be part of an organization in Kragujevac (a city in Serbia). In agriculture, of the 31 enterprises to which the violent measures were applied, 21 of them were integrated into Serbian enterprises. This is how the transfer of Kosovar wealth to Serbia was taking place, wealth which was being destroyed and looted day by day.

58 E. Bajçinovci, Variante të reja për kolonizimin e ri të Kosovës, "Bujku”, 14.VI 1991.

59 Arrests during this year were daily. During July and August several activists of The People's Movement of Kosovo and of The National Movement for the Liberation of Kosovo were arrested, for more see, "Zëri i Kosovës", Organ i Lëvizjes Popullore për Republikën e Kosovës, Year XII No.3, March 1993, p. 1. Nr. 13, August 1993, p. 1. Nr. September 14, 1993. p. 8. Nr. 14, September 1993, p. 1, no. 2, January 151994 , p. 4.

60 "Aksioni i grumbullimit të armëve - mjet presioni për spastrimin etnik në Kosovë", (Weapons collection action - a means of pressure for ethnic cleansing in Kosovo), "Zëri i Kosovës", Year XI, no. 3, 16 March 1993. The year 1994 followed by further increasing the violence of the occupiers against the Albanian population. During this year alone, 5407 families have been raided, 660 interventions have been made in institutions, 5026 people have been interviewed, 1526 individuals and business activities have been robbed, 777 passports have been confiscated, 3436 psycho-physical abuses have taken place, 2868 arrests have been made within 30 days, 555 court proceedings were opened, 4008 beatings were committed, 263 people were sentenced to prison, 16 murders were committed, 305 refugees were returned, 109 young people were forcibly taken into the Serbian army and 23 people were injured. "Zëri i Kosovës”, Organ i Lëvizjes Popullore për Republikën e Kosovës, Year XIII, no. 4, no. 15 February, 1995 , p. 8. 
the construction of 61,024 previously planned dwellings was foreseen. These legal provisions also defined the conditions and criteria for the allocation of loans and housing for certain categories, such as "staff" and people returning to Kosovo. In addition, it was planned to allocate land for the construction of houses for colonies, etc. ${ }^{61}$

Slobodan Milosevic directed all state mechanisms at that time to the detriment of Kosovo, always to fulfill the promises and the Pan-Slavic obligation: the expulsion of Albanians from Kosovo and its colonization with Slavs from various Yugoslav regions. On January 12, 1995, the Yugoslav government approved a decree allocating 4.1 million dinars from the 1995 federal budget for the construction of colonies in Kosovo. ${ }^{62}$ This decree invited all interested parties, cadres of different profiles and professions, all citizens displaced from Kosovo, who were interested in returning, that they would receive loans with a repayment period of 40 years. They would also be given free land. With the approval of this decree, it was planned to settle about 100,000 Serbs and Montenegrins in Kosovo. ${ }^{63}$

Serbia intervened in every pore of life, always issuing legal acts in order to "prevent the displacement of Serbs and Montenegrins from Kosovo", while, on the other hand, putting pressure on Albanians for displacement, with an ultimate goal: the realization of ethnic cleansing of Kosovo. ${ }^{64}$ To this end, Serbia issued a law defining the sale and purchase of real estate. According to this law, the decision-making authority for the sale and purchase of property, private property, was the Republican Secretariat of Finance of Serbia. The decision to sell was made only if this action did not affect the change of ethnic structure. This law applied only in Kosovo. According to it, hundreds of sales contracts were canceled. Many hectares of land and hundreds of houses and flats were taken from the Albanians. ${ }^{65}$

In order to realize the colonization of Kosovo, Serbia undertook concrete actions, such as changing Kosovo's urban plans. Despite the fact that they were in conflict with the spatial laws, the Assembly of Serbia, in this regard, approved decisions, such as: The decision to change and supplement the detailed urban plan of the neighborhoods "Ulpiana" and "Dardania" in Pristina.

61 Osmani, Kolonizimi Serb, P.166.

62 Rifat Blakut, Srbija institucionalno radi na kolonizaciji Kosova, 204-205, 207 (më tej: Blaku, kolonizaciji Kosova).

63 Blaku, kolonizaciji Kosova, 207.

64 During 1995, 16 homicides were recorded, 6 as a result of violence at police stations. 3487 people were arrested, during the action of the weapons collection operation 3810 people were mistreated, 2234 families were raided among which the most tragic victims were children, the elderly and women, where as a result of these raids 506 women, 611 children and 157 people of different ages were traumatized . In order to intimidate, but above all in order to empty Kosovo of the Albanian people, 31 children, women, the elderly and other members of the persecuted families were taken hostage in order to report their persecuted relatives to the police . During this year, 315 people were convicted, all of whom were sentenced to 540 years in prison. Of the 105 youths who were arrested for failing to respond to a call for military service, 25 were handed over to the military court, while 13 were handed over to the military court for desertion. During this time 1635 young Albanians were invited for military service in the Yugoslav army . During this year, 507 victims of terror were also from the ranks of pupils, students and teachers, as well as 130 interventions were registered in educational institutions. "Zëri i Kosovës ”, Organ i Lëvizjes Popullore për Republikën e Kosovës, Year XIV, no. 5, February 1, 1996, p. 3.

65 Hysen Ibra, Shkatërrimi i hapësirës së Republikës së Kosovës nga okupatori serb (1989-1997), Prishtina 1998, p. 97. (hereinafter: Ibra, Shkatërrimi i hapësirës). 
With this change, it was planned that in the neighborhood "Ulpiana", instead of sports facilities of the primary schools, 110 apartments would be built for Serbs and Montenegrins who wanted to return to Kosovo. Whereas in the neighborhood "Dardania" it was planned that instead of the locality for greenery, there were to be built 98 apartments for Serbs and Montenegrins. ${ }^{66}$ Within these decisions was also the one for the construction of cult houses, orthodox churches, as was the case of the church in the university premises in Prishtina.

The Federal Republic of Yugoslavia (FRY), which was dominated by Serbia, from the circumstances created after the wars in Slovenia, Croatia, Bosnia and Herzegovina, wanted to use the population there as a good opportunity for the fastest colonization of Kosovo and the change of ethnic status in the service of its interests. In the framework of this goal, on January 12, 1995 , Serbia drafted the decree "On the manner and conditions of colonization of Kosovo". According to this decree, for the 100,000 Slavic settlers, it was planned to give free land (to those who wanted to engage in agriculture would also be given three hectares of agricultural land), flats, houses and financial means and large sums. ${ }^{67}$

In 1995, 13.895 Serbian colonists who came from Bosnia, but also from Serbia were placed in Kosovo. According to the plans, Serbian colonization, initiated by Milosevic, was planned to bring tens of thousands of Serb refugees from Croatia and Bosnia and Herzegovina to Kosovo ${ }^{68}$ Slavic colonies, from one or two families, were also settled in the facilities of working organizations, entities, institutions, factories, etc., where they were employed. Violating every international law, Slavic colonies were also placed in archive objects, such as the Kosovo Archive (KA) and the City Archive of Prishtina (CAP), etc. ${ }^{69}$ The Serbian government paid the settlers high salaries and exempted them from all payments, such as electricity, telephone expenses, municipal taxes, and even travel expenses.

The Serbian government, in order to entice the Serb population to settle in Kosovo, for the Slavization of Kosovo, issued various laws, decrees and plans. One such law was the "Law on the conditions, manner and procedure of allocating agricultural land to citizens who wish to live and work in the territory of the Autonomous Province of Kosovo and Metohija ." The Serbian government, wanting at all costs to strongly advance the projects launched against Albanians, continued with harassment, beatings, obstruction of the educational process, kidnappings, rapes, imprisonment and murder of Albanians. ${ }^{70}$

66 Osmani, Kolonizimi serb, p. 168.

67 Ibra, Shkatërrimi i hapësirës,p. 156; Osmani, Kolonizimi serb, p. 169.

68 Ibra, Shkatërrimi i hapësirës, p. 190.

69 Osmani, Kolonizimi serb, p. 170.

70 According to the Council for the Protection of Human Rights and Freedoms reports, in April 1997 alone, 272 people were ill-treated, while 3 others were killed. “Zëri i Kosovës”, Organ i Lëvizjes Popullore për Republikën e Kosovës, Year XV, no. 13, April 3, 1997, p .9. and No. 20. 22 May 1997. p. 14. From 20-30 May 1997 a trial was held against 20 members of the National Movement for the Liberation of Kosovo (NMLK), who as a group were sentenced to 107 years in prison . "Zëri i Kosovës", Organ i Lëvizjes Popullore për Republikën e Kosovës, Year XV, no. 23, 12 June 1997, p.7. What shocked the judges of the Serbian "trial panel" was the noble act, the engagement of Shukrije Rexhe and Avni Klinaku, which was announced during the court session. This engagement was in itself a testament to the future and a human struggle, more than waiting for punishment, this engagement testified to the dream of the future. 
With the public appearance of the KLA (28.11.1997), with the beginning of hostilities, at the end of 1997 and onwards, in 1998 and 1999, the Serbian criminal regime exceeded all international laws regarding the observance of human rights, national and international rights, committing a classic genocide against the Albanian people. The Serbian army, police and paramilitary forces not only killed innocent civilians ${ }^{71}$, not only did they burn and destroy everything that was Albanian, but these forces also committed one of the most serious acts against man, the act sanctioned and punished by international laws, committed the most serious and macabre act against humanity, such as sexual assault against the population, regardless of gender or age. ${ }^{72}$

In war circumstances, the ruling Serbian political party, the Socialist Party of Serbia (SPS), namely the "SPS Provincial Council for Kosovo and Metohija", made plans and drafted projects for the "solution" of the Kosovo issue; its Serbization. On December 15, 1998 in Prishtina, it drafted a document entitled "Proposal of measures to solve the current problems in Kosovo and Metohija" ("Predlog mera za reshavanje aktualnih problema na Kosovë i Metohiji"). ${ }^{73}$ One of the infamous anti-Albanian projects in the late twentieth century was undoubtedly the military operation codenamed "Patkoi". The operation was a project of the Yugoslav Army Headquarters and Slobodan Milosevic. ${ }^{74}$ This project for the destruction of Albanians is a continuation of previous anti-Albanian projects, from "Naçertanija" by Ilia Garashanini to "Memorandum ..." of the Academy of Sciences and Arts of Serbia, whose creator was the chauvinist writer and politician Dobrica Qosiq. ${ }^{75}$

71 When we talk about the Serbian security forces, we have often read and heard about their number and designation. More precisely, in addition to the regular military and police forces, referring to various reports from the war, as well as post-war studies, in Kosovo, as Serbian forces have also been engaged paramilitary forces. However, what we must keep in mind is that these forces have been led by personalities of the political scene, such as Vojislav Seselj, but also by personalities close to the Serbian regime, such as Zeljko Arznjativic Arkan. Therefore, when we talk about these forces, in the case of Kosovo we must consider that behind these formations stands the Serbian state itself, and as such has been used to hide the crime of the Serbian regime. Bardhyl Mahmuti in his study, Terminological traps, in order to deny the genocide in Kosovo, with full competence and right states that: "Concealing the crime of genocide committed in Kosovo by Serbian armed forces and pointing the finger at "Paramilitary groups" is part of Serbia's strategy to escape responsibility as a state."

72 Article 5, Crimes against humanity. The International Tribunal shall have the power to prosecute individuals responsible for the following crimes committed during an international or domestic armed conflict, and directed against any civilian population: (a) Murder; (b) extermination; (c) captivity; (d) eviction; (e) imprisonment; (f) torture; (g) rape; (h) persecution on political, racial and religious grounds; (i) other inhumane acts.

73 The introduction to that project stated, among other things: "For Kosmet to remain under Serbia, the most important thing is for Serbs and Montenegrins to remain in these territories. In order to preserve Kosovo and Metohija, the state must take urgent measures to eradicate terrorism, raise the economic and social position of Serbs and Montenegrins and create conditions for the colonization of these areas."

74 According to international reports in the early years of the war, as well as according to various scholars , not only from Kosovo, there were 11.840 civilians killed in Kosovo. Of them, 1,392 children up to the age of 18,296 children up to the age of $5,1.739$ women and 1.882 elderly people over the age of 65 , to this day 1.600 inhabitants are missing and 20.400 Albanian women have been raped. Also there was the destruction of 100,589 houses and 88.101 accompanying facilities, 358 schools, 30 cultural houses, 93 libraries, 123 health institutions and 220 religious places of worship, mosques, tekkes. tombs and catholic churches. 


\section{Conclusion}

In line with above, in regards to the anti-Albanian policy of the Serbian state, programs and methods of Serbian occupation and colonization, by presenting the emergence and development of nationalism in the Balkans, respectively Serbian nationalism, and by not deviating from the universal principles, it is concluded that this nationalism was in harmony with the emergence and development of nationalism throughout human society of the XIX and XX centuries. Characteristic of this nationalism was that it had the pan-Slavic program or idea as its initial guidance, which was initiated by the Orthodox Church. It is worth noting that these projects for the creation of the PanSlavic Empire were executed exactly by the Serbian Autocephalous Church on the nations in the Balkans, and especially on the Albanians.

Evidently, such anti-Albanian actions, since "Naçertania" were taken continuously through the programs of Nikola Pasic, Vuk Karadzic, Vasa Çubriloviqit, Ivo Andric, through the YugoslavTurkish Agreement of 1938, the so-called "Gentlemen's Agreement" between J.B. Tito and the Turkish state in 1953, through the Memorandum of the Academy of Sciences and Arts of Serbia, up until the end of the last century, when Slobodan Milosevic appeared on the Serbian political scene.

It is clear that Serbian policies consistently, especially in the time of Slobodan Milosevic, were presented as a political calculation of the medieval church and diplomacy to rule over other nations. Milosevic was the protagonist of the last decade, who wanted through new fabricated projects (laws, decrees, plans, etc.), to stage once again the pan-Slavic plan of "Nachertania" and that in the most brutal form, as Serbia had done in 1877-1878 in the Sandzak of Nis against the Albanians.

The period of S. Milosevic's rule was a continuation of the anti-Albanian program between the governments. He had finally implemented a policy of genocidal proportions, a policy for the removal and annihilation of Albanians from their lands, respectively the Serbization of Kosovo.

The Milosevic regime, after the occupation of Kosovo, from 1989 to 1998, through its own mechanisms, science, culture and education, as well as through security mechanisms, poisoned students and teachers, arrested hundreds of professors, students, political figures of science, art and culture, and in almost all Kosovar institutions dismissed thousands of workers and imposed extraordinary measures to do so. It transferred and integrated over 200 state-owned enterprises into Serbian ones, it changed the names of various schools, streets, squares, institutions and organizations, naming them after the Serbian church and state personalities, as well as after the names of Albanian collaborators. He staged cases like the one in Paraqin, on September 3, 1987 , and from that year 120 Albanian youths serving in the Yugoslav army were returned in coffins, displaced and expelled from their lands, additionally, the destruction of many households occurred.

During the 1998-1999 liberation war, the Serbian regime, through the security forces, undertook genocidal actions aimed at the annihilation of the Albanian people from Kosovo, and finally the population of Kosovo with a Slavic element. Thousands of civilians have been killed, of them were hundreds of children of different ages, thousands of women and the elderly over 65 years, thousands of people are missing and thousands of differently aged men and women have been raped. Thousands of houses and ancillary facilities, dozens of cultural houses and libraries, hundreds of schools, health institutions and places of worship, mosques, tekkes, catholic churches, 
and tombs were also destroyed.

All these anti-Albanian actions on the scale of genocide are best illustrated by the statement of the Serbian writer and analyst Mirko Gjorgjeviç, "Hundreds of memoranda and plans have been made to resolve the Kosovo issue. When one looks at these solutions to the problem, be they communist, state or church, one will easily notice that all those plans were to resolve the issue of Kosovo, so that there are no Albanians there."

But, fortunately, such an anti-Albanian policy will be flooded with the just Liberation War during the years 1998-1999, a war led by the Kosovo Liberation Army and supported by the international factor, both political and military one.

In conclusion, the Liberation War brought freedom and paved the way for resolving the political and legal status of Kosovo.

\section{Bibliography:}

“Ceh u sluzhbi serbije”, Politika online, 11 janar 2014.

Aliu, Hamdi Rezalla në rrugëtim lirie”, Prishtinë, „Europrinty”, Prishtinë, 2008.

Arifi Bakalli, Emine "Përpjekjet e Komitetit ' $M K K$ ” për denoncimin e dhunës dhe mbrojtjen e të drejtave kombëtare e demokratike të shqiptarëve në Jugosllavi”, në përmbledhje kumtesash, Komiteti Mbrojtja Kombëtare e Kosovës, Akademia e Shkencave, Tiranë, 2004.

Ayşe Özkan, Miloştan Milin ‘a Sirp Bağimsizliği (1830-1878), (Nga Milloshi tek Millani Pavarësia e Serbisë), IQ Kültür Sanat Yayıncılı, Stamboll, 2011.

Bajrami, Hakif, Kosova Njëzet shekuj të identitetit të saj, „Era”, Prishtinë, 2001.

Bajrami, Hakif, Naçertania Program politik serb që shpie në shfarosjen e shqiptarëve 18441999, „Shkrola”, Prishtinë, 2004.

Bajrami, Hakif, Peticioni që $i$ shpëtoi shqiptarët në Shqipërinë Kontinentale nga fashizmi serb, "Shkrola" Prishtinë, 2005.

Bajrami, Hakif, Politika e shfarosjes së shqiptarëve dhe kolonizimi serb I Kosovës (18441945), Prishtinë, 1995.

Bajrami, Hakif, Si e okupoi Serbia Kosovën më 1912, pjesa e parë, Prishtinë, "Shkrola", 2003.

Bejtullah Destani, Muhaxhirët (Dosja Britanike, spastrimi etnik i Toplicës, Nishit, Prokuplës, Kurshumlisë, Leskovci, Vranjës 1878-1884, Prishtinë, “Artini”, 2019.

Beka, Alfred, Memorandumi i Mirëkuptimit, gazeta "Ekspres”, Prishtinë, dt. 11.01.2014.

Braha, Shaban, Idriz Seferi në Lëvizjen Kombëtare Shqiptare, Tiranë, 1982.

Bugajski, Janusz, Ngritja e Kosovës - Artikuj dhe fjalime nga okupimi deri te pavarësia, „Koha”, Prishtinë, 2006.

Cokić, Jevrem, Početak Kraja, “Srpska Knjiga”, Beograd, 2008.

Çeku, Ethem, Shekulli i Ilegales-Proceset gjygjësore kundër ilegales në Kosovë, Dokumente, 
Prishtinë, "Brezi 81”, Prishtinë 2004.

E. Bajçinovci "Variante të reja për kolonizimin e ri të Kosovës”, "Bujku”, 14.VI 1991.

Gjorgjeviq, Vladan, Arnauti i Velike Sile, Beograd, 1913.

Haxhibeqiri, Fuat, Monografi e krimeve të luftës në Gjakovë 1998-1999, Gjakovë, 2011.

Ibra, Hysen, Shkatërrimi i hapësirës së Republikës së Kosovës nga okupatori serb (19891997), Prishtinë 1998.

Kemal H. Karpat, Popullsia Osmane 1830-1914 Karakteristikat demografike dhe shoqërore, Tiranë, Alsar 2017.

Kola, Harila. Gjenocidi serb ndaj shqiptarëve në viset e tyre etnike në Jugosllavi”, 19411967, Tiranë, 2000.

Krasniqi, Jakup, Pranvera e lirisë'81, Prishtinë, “Buzuku”, 2011.

Lahu, Riza, Golgota shqiptare, Tiranë, 1995.

Lalaj, Ana, Kosova -Rruga e gjatë për vetëvendosje, Tiranë, 2000.

Malcom, Neol, Kosova një histori e shkurtër, Botimi i dytë, përktheu nga anglishtja Abdullah Kajragdiu, Prishtinë, “Koha”, 2001.

Muhamet Pirraku, Myderiz Ymer Prizreni, Prishtinë, "Koha”, 2003.

Nushi, Pajazit, Krimet e Gjenocidit të Serbisë ndaj shqiptarëve në Kosovë, KMDLJN, Prishtinë, "BULETINI", nr. 14, janar-mars 2000. 1981.

Obradović, Milovan, Agrarna reforma i Kolonizacija në Kosovu 1918-1941", Prishtinë,

Osmani, Jusuf, Kolonizimi serb i Kosovës, Prishtinë: ERA 2010.

Osmani, Jusuf, Krimet e Serbisë në Kosovë 1998-1999, Libri 1.

Qosja, Rexhep, Shpërngulja e shqiptarëve sipas programeve kombëtare serbe, Tiranë, "Toena", 2005.

Reuter, Jenes, Shqiptarët në Jugoslavi, përkthim nga Nestor Nepravishta, Tiranë, “Impex”.

Rifati, Fitim, Kosova gjatë Luftës së Parë Botërore 1914-1918, Prishtinë: Instituti i Historisë - Prishtinë, 2019.

Stançiç, Niksa, Problem "Nacertanija” Ilije Garasanina u našoj historiografije, Historijski Zbornik, godine XXI-XXII, 1968, Povijesno drustvo Hrvatske, Zagreb.

Shatri, Bajram, Arsimi shqip në Kosovë 1990-1999 - shtëpitë shkolla, sfidat, arritjet dhe aspiratat, "Libri shkollor", Prishtinë, 2010.

Uka, Sabit Dëbimi i shqiptarëve nga Sanxhaku i Nishit, 1877/78, Prishtinë, I, 1994.

Uka, Sabit, Planet antishqiptare të shteteve fqinje në shekullin XIX, Kosova në rrjedhat ballkanike, Prishtinë, 1996. 


\section{Newspapers:}

“Zëri i Kosovës" Zurich.

"Kombi", Prishtina.

"Bota sot", Prishtina.

"Bujku”, Prishtina.

"Flaka", Skopje.

"Koha ditore", Prishtina.

"Kosova sot", Prishtina.

"Rilindja", Prishtina.

"Ekskluzive", Prishtina.

"Politika", Belgrade. 